УДК $811.111 ' 255.4=161.1=161.2$

DOI https://doi.org/10.26661/2414-9594-2020-2-5

\title{
ПЕРЕКЛАДАЦЬКІ ІНТЕРПРЕТАЦІЇ ЗАГОЛОВКІВ ЦИКЛУ ГУМОРИСТИЧНИХ ОПОВІДАНЬ М. БОНДА
}

\author{
Володарська М. В. \\ кандидат філологічних наук, \\ доиент кафедри іноземних мов \\ Льотна академія \\ Національного авіаційного університету \\ вул. Добровольського, 1, Кропивницький, Украӥна \\ orcid.org/0000-0002-6060-2084 \\ changariki@gmail.com
}

\author{
Ключові слова: оповідання \\ М. Бонда, гумор, \\ інтерпретація тексту, \\ переклад заголовку, \\ еквівалентність, кониепт, \\ дитяча література.
}

У статті зроблено спробу проаналізувати характерні ознаки гумористичного складника заголовків циклу М. Бонда «Пригоди ведмедика Падінгтона», визначити особливості відтворення комізму і причини його можливих втрат в українській та російській перекладних версіях, окреслити межу проникнення етноспецифічного гумору в тексти літератури для дітей. Вибір об’єкта дослідження зумовлений намаганням подолати протиріччя між наявністю розлогого літературного матеріалу (13 книг, 99 оповідань) та тривалим ігноруванням потенціалу тексту науковою спільнотою. Короткий огляд надбань з теорії заголовку (С. Кржижановський, У. Еко, В. Кухаренко, А. Еткінд) дозволив визначити такі риси назв, як амбівалентність, полісемантичність, здатність акумулювати головний концепт художнього твору тими причинами, що значно ускладнюють розкодування і ретрансляцію жарту. Лінгвістичний гумор завжди чинить опір перекладачеві, оскільки вимагає збереження не лише змісту, але і форми повідомлення, тому пошук найбільш прийнятних алгоритмів досягнення еквівалентності становить пріоритетне значення.

Попри позірну прозорість сюжету, заголовки текстів М. Бонда подеколи акумулюють цілий кластер соціокультурних уявлень, породжених актуальними для Британії періоду 1950-1960-х років питаннями «інакшості». Концепт "trouble" $\epsilon$ визначальним для циклу «Пригоди ведмедика Падінгтона». Відповідний концепт реалізується в низці назв ("A Bear in Hot Water", "Sticky Time", "Paddington in a Hole") за посередництва етноспецифічних алюзій та каламбурів; намагання відобразити ці нюанси виводить наратив М. Бонда на межу перекладності. Прагнення I. Бондаря-Терещенка до максимальної еквівалентності не завжди рівнозначне прозорості англійського гумору для маленького читача; нарощування експресії і додавання жарту А. Глебовською та К. Сиверцевою спричиняє зміну тональності й наративного фокусу каламбурних утворень окремих заголовків. Відмінні продуктивні моделі відтворення гумору можуть бути результатом різних уявлень про специфіку дитячої книги. Питання як та якою мірою слід виводити у заголовок жарт, заснований на реаліях, залежатиме від вибору перекладачем стратегії «одомашнення» комічного чи збереження національного колориту. 


\title{
TRANSLATION INTERPRETATIONS OF THE TITLES OF HUMOROUS SHORT STORIES BY MICHAEL BOND
}

\author{
Volodarska M. V. \\ Candidate of Philological Sciences, \\ Associate Professor at the Department of Foreign Languages \\ Flight Academy \\ of the National Aviation University \\ Dobrovolskogo str., 1, Kropyvnytsky, Ukraine \\ orcid.org/0000-0002-6060-2084 \\ changariki@gmail.com
}

Key words: Michael Bond's stories, humor, text interpretation, title translation, equivalence, concept, children's literature.

\begin{abstract}
The article is an attempt to analyze the peculiarities of the humor component in story titles of "Paddington Bear's Adventures" by Michael Bond. The attention is paid to such problems as the original humor reproduction and the possible loss of meaning in Ukrainian and Russian text versions. The degree to which ethnic humor can penetrate into children's books is also under investigation. The choice of the research object can be explained by a contradiction between a huge amount of actual literary material (13 books, 99 stories) and a long-lasting scientific disregard of the text potential. A short review of works on title theory (S. Krzhizhanovsky, U. Eco, V. Kukharenko, A. Etkind) allowed us to identify such title characteristics as ambivalence, polysemy and the ability to accumulate the major text concept as the important reasons which perplex the decoding and translatability of a joke. The linguistic humor is always resistant because it requires both the form and the sense consideration. That is why the search of the most appropriate equivalence achievement methods is of primary importance. Despite the external simplicity of the plot, Michael Bond's text titles often accumulate a cluster of social and cultural perceptions caused by the urgent British problems of the 1950-1960s, the problems of "Otherness". The concept "trouble" was recognized as the main one for Paddington Bear Series. This concept is reflected in several titles ("A Bear in Hot Water", "Sticky Time", "Paddington in a Hole") with the help of cultural allusions and puns; the endeavor to reproduce these shades of meaning moves the titles to the boundary of translatability. I. Bondar-Tereshchenko's desire to achieve maximum identity in his translation is not always tantamount to the explicitness of English humor for a young Ukrainian reader. The intensive usage of additional jokes by A. Glebovska and K. Sivertseva changes the tone and focalization of some title messages. The different humor reproduction models can result from different children's book visions. The question of how and to what degree a foreign joke can penetrate into the title depends on the translator's choice between the two trends: either domestication or Anglicization of a humorous story.
\end{abstract}

Постановка проблеми. Проблема інтерпретації комічного елементу художнього тексту не припиняє викликати інтерес українських і закордонних науковців. Переклад гумору - а надто гумору етноспецифічного, англійського, прегнантного обертонами імпліцитних смислів - часто є тим самим «твердим горішком», котрий стимулює чисельні дебати 3 приводу «неперекладності» іншомовного меседжу. Оскільки навіть за умови збігу когнітивних сценаріїв гумористичної поведінки, розуміння може бути обтяженим наявністю інформаційних лакун у представників різних лінгвокультурних спільнот $[1$, с. 252$]$, гумористично забарвлені твори дитячої літератури подеколи чинитимуть подвійний опір зусиллям тлумача. Тому встановлення «межі перекладності» $[2$, с. 6] англійського гумору в текстах для дітей $\epsilon$ актуальним, особливо якщо йдеться про ті його зразки, котрі раніше не привертали уваги перекладознавців.

Вибір текстів М. Бонда як об'єкта дослідження зумовлений насамперед наявністю розлогого 
матеріалу: 13-томний цикл (99 оповідань) було створено протягом 1958-2012 років і перекладено на більш ніж 30 мов. Перший український переклад у виконанні I. Бондаря-Терещенка вийшов у видавництві «Ранок» 2014 року, до того часу знайомство українців 3 лондонською історією ведмедика-іммігранта опосередковувалося російською версією А. Глебовської й К. Сиверцевої. Репрезентований Падінгтоном концепт «інакшості» періодично потрапляє у фокус уваги адептів постколоніальних студій [3]. Однак зміщення акцентів на дешифрування соціального коду зумовлює маргіналізацію важливого аспекту, що визначає економічну перспективу оповідань М. Бонда як тексту літератури для дітей: гумористичного складника заголовку.

Мета цієї розвідки полягає в аналізі специфіки комізму заголовків оповідань М. Бонда та з'ясуванні характеру відтворення цих особливостей в українській і російській перекладних версіях.

Виклад основного матеріалу дослідження. Сучасна теорія заголовку балансує між двома полюсами його інтерпретації, репрезентованими у вигляді афоризмів С. Кржижановського («Поэтика заголовка», 1931) та У. Еко («Нотатки до роману «Ім'я троянди»», 1983). Канонічне вже уявлення К. Кржижановського про конденсовану згортку, що запускає процеси розкодування тексту, здатного, своєю чергою, бути оприявненим у назві («Книга і є розгорнутий до кінця заголовок, заголовок - стягнута до об'єму двох-трьох слів книга $[4$, c. 3]») $\epsilon$ визнанням заголовку як домінантного орієнтиру для реципієнта. Через 50 років після виходу мікрофонографії К. Кржижановського У. Еко полемізуватиме із наведеним твердженням, закликаючи у своєму постскриптумі-парадоксі до максимальної нейтралізації семантики 3 метою дезорієнтування читача: «Назва повинна заплутувати думки, а не дисциплінувати їх» [5, с. 6].

Насправді дисонанс між визначеннями $є$ дещо перебільшеним. Обидва твердження, по-перше, акцентують сильну позицію першого знаку тексту. Побоювання У. Еко щодо надмірної інформативної ваги заголовку спричинені усвідомленням наявності глибинного зв'язку між текстом та його назвою, завдяки чому текст, «ця багатошарова система означаючих», постає «означуваним стосовно свого заголовку» [6, с. 159]. По-друге, i С. Крижижановський, і У. Еко підкреслюють роль заголовку в актуалізації авторського концепту. У. Еко не заперечує закарбованості в назві текстової програми, хоча і супроводжує свою тезу ремаркою «на жаль». Неспроможність читача надати перевагу жодній конкретній інтерпретації («заплутування думок») до моменту повного розгортання тексту $є$ очевидним наслідком паралельної динаміки процесів оформлення текстової концептосфери і нарощення змісту заголовку - актуалізатора головного концепту [7, с. 96]. При цьому обов'язкове ретроспективне осмислення заголовку («рамкового знаку» [7, с. 92]) завжди виявлятиме семантичні зсуви та нетотожність об'єму значень на вході і на виході з текстової площини $[7$, с. 100]. По-третє, тези С. Кржижановського та У. Еко імплікують виконання заголовком низки функцій, зокрема рекламної, що, за В. Кухаренко, передбачає привертання уваги читача, встановлення 3 ним контакту та спрямування його очікувань [7, с. 95]. Опоетизовані У. Еко нескінченні «нові тлумачення» [5, с. 6] пов'язані 3 амбівалентністю заголовку, котра знімається тільки в результаті оприявнення авторських концептів і здатна провокувати «ефект обманутого очікування» [7, с. 95]. Полемізуючи з У. Еко 3 приводу ролі цього ефекту для потенційного читача, В. Кухаренко, власне, визнає комерційне значення гіперсемантизованої назви, іiі потужний стимул, що спонукає реципієнта до заповнення інформаційних лакун за рахунок індивідуальних асоціацій. При цьому інтертекстуальність і метафоричне навантаження назви, каталізуючи процес прогнозування $[8$, с. 91$]$, сприяють успіху літературного продукту на видавничому ринку.

Однак успішність оригіналу не обов'язково дорівнює успішності перекладу, зокрема, і через здатність усіх вищенаведених ознак заголовку гальмувати процес укорінення первинного меседжу в новому інтертекстуальному просторі. Адже зміна простору означає старт діалогу тексту 3 іншим смисловим універсумом, що викликає певний семантичний зсув у характері паратекстуальних відносин між текстом та його назвою [8, с. 93]. Стислість і недескриптивність сучасного заголовку, наділеного енергією «туго згорнутої пружини» [7, с. 92-94], мають своїм наслідком ускладнення експлікації та унеможливлення імплікації змісту без втрати щонайменше частини оригінального коду $[9$, с. 80]. Особливо відчутними виглядають ці втрати під час перекладу гумористичного елементу заголовку, зокрема каламбуру, де «ніби у фокусі зібраний весь ідейний зміст такого твору, виражений максимально точно авторський задум, а це, за відсутністю контексту $<\ldots>$, надзвичайно важко відтворити» $[10$, с. 288$]$. Основною причиною опору лінгвістичного гумору С. Влахов та С. Флорін називають необхідність перекодування не лише змісту, але і форми, подеколи важливішої за зміст. Оскільки умовою збереження обох компонентів $є$ наявність повної еквівалентності між фразеологічними зворотами мови оригіналу і мови перекладу, адекватне відтворення жарту видається радше винятком, ніж правилом [10, с. 290-291]. Виклик лінгвістичного гумору стимулює науковців до пошуків єдиного алгоритму перекладу. 
П. Забалбеско запропоновав ієрархічну схему "binary branching tree", - кожен наступний щабель якої, починаючи 3 другого, становить зумовлений об'єктивними перешкодами компроміс: продукування ідентичного жарту $\rightarrow$ відтворення жарту аналогічного типу $\rightarrow$ формування будьякого жарту $\rightarrow$ компенсація за рахунок іншого стилістичного засобу $\rightarrow$ нейтралізація жарту [11, с. 199-200]. Серед порад А. Лібольда тлумачеві на випадок відсутності функційного аналогу О. Підгрушна виокремлює: усунення комізму, буквальний переклад, перекладацький коментар, одразу ж, втім, полемізуючи з дослідником щодо адекватності вибраних шляхів. Адже оскільки передумовою сміху завжди $\epsilon$ непередбачуваність, «гумор через пояснення втрачає силу свого ефекту» [2, с. 51$]$.

Усвідомлення існування межі, за якою «мова оригіналу таки утримує монополію на гумор» [2, с. 54], часто орієнтує науковців на збереження під час перекладу гумористичних текстів радше «інваріантного ядра» (А. Попович) [2, с. 53], аніж кожного конкретного випадку мовної гри. 3 огляду на те, що мета гумору - «рушія перекладу» - може контрастувати з метою кінцевого споживача гумористичного продукту, питання полягає у пошуку найбільш прийнятного за конкретних обставин способу поєднання «стилістики і прагматики» $[2$, c. 54]. У ситуації із комічно забарвленим заголовком таке завдання $\epsilon$ хоча $\mathrm{i}$ результативною, однак не завжди легкою справою.

Комерційний успіх 13-томного проєкту М. Бонда [12] був не останньою мірою спричинений гумористичною тональністю циклу: маркер "funny story" позиціонується в рецензіях англійських, а згодом і закордонних читачів як головний імператив у разі вибору книги. Однак, попри застосування письменником широкого спектра мовних ресурсів для відтворення ситуативного жарту, заголовки багатьох оповідань $\epsilon$ стилістично нейтральними, можуть бути розглянуті крізь призму комічного хіба лише ретроспективно. Нейтральними, якщо не брати до уваги момент прегнантності тексту новизною на початку 1960 -х років, коли для англійськомовного реципієнта онім «Падінгтон» був передусім топонімом. Контамінація неживого суб'єкта й активного предикату [6, с. 562] видавалася дивною, однак доволі оптимістичною, та, імовірніше за все, викликала у маленького читача усмішку. Приміром, назва "Paddington Turns Detective"/«Падінгтон стає детективом» у контексті українських реалій могла нести той же заряд комізму, як і щось на зразок «Хрещатик стає детективом». Проте вірогідна обізнаність дорослого реципієнта зі значенням ідіоми "to dance the Paddington frisk” («бути повішаним», пов’язане 3 викорис- танням у минулому площі біля вокзалу як місця масових страт) $[13$, с. 264$]$ актуалізувала амбівалентне забарвлення топоніму, додаючи, особливо 3 огляду на трагічні події 1958 року у Нотінгемі, фразам "Paddington Prepares", "Paddington Saves the Day", "Paddington hits out" виразного відтінку чорного гумору. Отже, на етапі першої рецепції твору принцип У. Еко було до певної міри реалізовано - адже заголовок під час розгляду його поза іншими компонентами паратексту дезорієнтував читача щодо змісту, виконуючи при цьому свою рекламну функцію. Розуміння I. Бондарем-Терещенком лакунарності таких заголовків оприявнюється у доповненні оніму «Падінгтон» дескриптивним номінативом «ведмедик 3 Дрімучого Перу». Цей мікрокоментар, хоча і дискутивний 3 точки зору еквівалентності, $\epsilon$, тим не менш, цілком прийнятним: адже часопросторова відстань між англійським адресатом першодруку та сучасним українським читачем перешкоджає дешифруванню у назві антитези «неживе - живе», і тому унеможливлює виконання заголовком раніше закладеного гумористичного потенціалу.

Відлунням ситуативного гумору $\epsilon$ досить частотна поява у назвах лексеми "trouble" (“an unfortunate or distressing position; misfortune; civil disorder, disturbance or conflict" [14, с. 1409]), імпліцитно дотичної до постаті Падінгтона. Входження компонента "trouble" до складу концепту «інакшість» віддзеркалювало загальнонаціональні тенденції кінця 1940-х -початку 1960-х років, коли внаслідок колоніальних війн та подальшої втрати Британією колоній було створено міф про загрозу порядку й національній ідентичності 3 боку чужинця-мігранта [15, с. 557-558]. М. Бонд інтенсифікує суспільні перестороги, повторюючи використання слова "trouble" у заголовках оповідань кожного нового тому протягом 1959-1962 років; тим виразнішим для читача постає контраст між очікуваним i реальним, між мізерністю причини («комічні витівки звірятка») та викликаним нею галасом. Такий різновид сміху, за В. Проппом, можна іменувати «багато галасу 3 нічого» [16, с. 148]. Гіперсемантизація слова "trouble" відбувається в тому числі і за рахунок накопичення в текстовій площині тих авторських сигналів, які дають уявлення про амбівалентність і багатоаспектність поняття: "trouble" - нещастя i "trouble" - «неприємність», "trouble" - «небезпека 3 боку мігранта» ("I don't mind him just thinking", said Mrs Brown (...). "It's when he actually thinks of something that the trouble starts" [17, с. 74]) й "trouble" - небезпека для мігранта ("Oh dear", he said to the world in general, "I'm in trouble again" $[17$, c. 62$])$.

Конденсована амбівалентність концепту “trouble" розпадається в українському перекладі 
на окремі семантичні складники, зокрема, і з відверто негативною конотацією (табл. 1).

Компонент «неприємність», без сумніву, наявний у досліджуваному концепті, однак Бондове "trouble", характеризуючись здатністю перетворюватись щоразу на свою антитезу, навряд чи може бути зведене до «неприємності». Переклад А. Глебовської й К. Сиверцевої тяжіє до іншої екстреми - зміна назви з метою вилучення проблемного елементу й уникнення контроверсійності прочитань. Так, заголовок "Trouble at Number Thirty-two" розчиняється у «Білому ведмеді», внаслідок чого акцент зміщено 3 оцінки подіï ("trouble") на iii евфемізовану сутність (виконання Падінгтоном ролі сніговика). Такі семантичні зсуви, що виникають у результаті використанняперекладачемправаадаптуватидитинноорієнтований текст [18], провокують деформацію соціокультурного коду. Адже саме на етапі першого виведення лексеми у заголовок ("Trouble at Number Thirty-Two") можна спостерігати процес акумулювання додаткових відтінків у семантиці стереотипного "trouble" i, як наслідок, зміну фокалізації: «Інший»- не джерело негараздів, а їх перманентний об'єкт. Прийнятнішим з точки зору відтворення Бондової ідеї "trouble" видається запропонований А. Глебовською та К. Сиверцевою варіант «переполох», котрий має досить широку амплітуду коливань змісту: від «загальної раптової тривоги» [19, с. 465] до «метушні» [20] i, за посередництва останнього компонента, виявляє здатність імплікувати згаданий уже мотив «багато галасу 3 нічого».

Реалізація цього мотиву на рівні заголовку репрезентована і в оповіданні "Something Nasty in the Kitchen" (у збірці "Paddington Helps Out", 1961). Перекладні варіації: «Страхіття на кухні» (I. Бондарь-Терещенко), «Чудо-юдо в кухне» (А. Глебовська). "Something Nasty" («страхіття») це химера, котра примарюється ведмедикові на кухні, хоча насправді гармидер було спричинено власними кулінарними спробами Падінгтона. Але "nasty" - це і клішоване таврування тубільця у пригодницькому романі періоду розквіту імперії, відроджене медіа-імперативами повоєнної доби. Звісно, чергову проєкцію стереотипних уявлень на образ «Іншого»-іноземця ще треба розгледіти. Однак навіть за відсутності у потенційного читача фонових знань, гумористичний ефект від «перетворення очікуваної загрози на ніщо» (коли переформатувати трохи, слідом за В. Проппом, відоме висловлювання I. Канта) [Цит. за: 16, с. 144] збережено, зокрема, i у перекладах. Причому в російській версії гумор відтворено у самому заголовку «Чудо-юдо в кухне», i не лише засобами фонетичної редуплікації. Домінування компонентів «чудак», «проказник», «затейник», «шутник» над поодиноким випадком «дикарь» [21, с. 630] у семантичному колі слова «чудо» викриває істину природу «чудовиська»-Падінгтона; раптове усвідомлення контрасту між удаваним і справжнім провокує сміх. До того ж перенесення прадавнього слов'янського Чуда-юда в реалії сучасної англійської кухні (вочевидь, замалої для архаїчної істоти і у буквальному, і в переносному сенсі) $\epsilon$ для маленького реципієнта несподіваним, i тому комічним. У такому аспекті доцільним було б використання зменшувального суфіксу в українській назві - «страховисько», адже «страхіття», взяте безвідносно до контексту, лишає мало простору для гумористичних асоціацій.

Цикл М. Бонда містить низку назв, котрі можна вважати каламбурними варіантами концепту “trouble", розбудованими на фразеологічній основі: "A Bear in Hot Water", "Sticky Time", "Paddington in a Hole" (табл. 2).

Комізм заголовку "A Bear in Hot Water" $\epsilon$ результатом нашарування переносного і буквального значень ідіоми "be in hot water" ("to be in trouble" [22, с. 358] / «у складному становищі»), спроєктованих на конкретного референта. Під час першого відвідування душової кімнати Падінгтон

Таблиця 1

Варіації перекладу лексеми "trouble" у заголовках

\begin{tabular}{|c|c|c|c|}
\hline $\begin{array}{l}\text { № } \\
\text { 3/II }\end{array}$ & Оригінал М. Бонда & Переклад I. Бондаря-Терещенка & $\begin{array}{c}\text { Переклад А. Глебовської, } \\
\text { К. Сиверцевої }\end{array}$ \\
\hline 1. & $\begin{array}{l}\text { Trouble at Number Thirty-Two } \\
\text { (In “More About Paddington”, 1959) }\end{array}$ & $\begin{array}{l}\text { Неприємності в будинку тридцять } \\
\text { два («Усе про Падінгтона. Пригоди } \\
\text { ведмедика з Дрімучого Перу») }\end{array}$ & $\begin{array}{l}\text { Белый медведь («Медвежжонок } \\
\text { Паддингтон. Новые приключения») }\end{array}$ \\
\hline 2. & $\begin{array}{l}\text { Trouble at the Laundrette } \\
\text { (In “Paddington Helps Out", 1961) }\end{array}$ & $\begin{array}{l}\text { Пригоди у пральні («Падінгтон } \\
\text { допомагає. Пригоди ведмедика з } \\
\text { Дрімучого Перу») }\end{array}$ & $\begin{array}{l}\text { Большая стирка («Медвежонок } \\
\text { Паддингтон спешит на помощьь») }\end{array}$ \\
\hline 3. & $\begin{array}{l}\text { Trouble at the Airport } \\
\text { (In "Paddington Abroad", 1961) }\end{array}$ & $\begin{array}{l}\text { Проблеми в аеропорту («Падінгтон } \\
\text { подорожує. Пригоди ведмедика з } \\
\text { Дрімучого Перу») }\end{array}$ & $\begin{array}{l}\text { Переполох в аэропорту («Медвежо- } \\
\text { нок Паддингтон за границей) }\end{array}$ \\
\hline 4. & $\begin{array}{l}\text { Trouble in the Bargain Basement } \\
\text { (In "Paddington at Large", 1962) }\end{array}$ & $\begin{array}{l}\text { Пригоди на розпродажу («Пригоди } \\
\text { ведмежсати Падінгтона. Пригоди } \\
\text { ведмедика з Дрімучого Перу») }\end{array}$ & $\begin{array}{l}\text { Приключения на распродаже } \\
\text { («Все о медвежсонке Паддингтоне») }\end{array}$ \\
\hline
\end{tabular}


Таблиця 2

Каламбурні версії концепту "trouble"

\begin{tabular}{|c|c|c|c|}
\hline $\begin{array}{l}\text { № } \\
\text { 3/II }\end{array}$ & Оригінал М. Бонда & Переклад I. Бондаря-Терешенка & $\begin{array}{c}\text { Переклад А. Глебовської, } \\
\text { к. Сиверцевої }\end{array}$ \\
\hline 1. & $\begin{array}{l}\text { A Bear in Hot Water (In “A Bear } \\
\text { called Paddington", 1958) }\end{array}$ & $\begin{array}{l}\text { Чайна церемонія } \\
\text { («Ведмежа на ім’я Падінгтон») }\end{array}$ & $\begin{array}{l}\text { Мокрая история («Медвеэжонок по } \\
\text { имени Паддингтон») }\end{array}$ \\
\hline 2. & $\begin{array}{l}\text { A Sticky Time (In “Paddington } \\
\text { at Large”, 1962) }\end{array}$ & $\begin{array}{l}\text { Липка пригода } \\
\text { («Пригоди ведмежати Падінгтона») }\end{array}$ & $\begin{array}{l}\text { Ириски в миске («Все о медвежонке } \\
\text { Паддингтоне») }\end{array}$ \\
\hline 3. & $\begin{array}{l}\text { Paddington in a Hole } \\
\text { (In "Paddington at Work", 1966) }\end{array}$ & $\begin{array}{l}\text { Падінгтон прорубує вікно у світ } \\
\text { («Падінгтон працюєє)) }\end{array}$ & $\begin{array}{l}\text { Как соседу окно прорубили } \\
\text { («Паддингтон занят делом») }\end{array}$ \\
\hline
\end{tabular}

перебуває у ситуації “trouble”, допоки не знаходить адекватний спосіб порятунку з переповненої ванни: намагається вичерпати воду капелюхом. І в українській, і в російській мові наявні фразеологічні аналоги, пов'язані з тематикою води: «попасти як муха в окріп» (укр.) / «попасться как кур во щи» (рос.) [23, с. 311]. Однак, по-перше, необхідна для утворення каламбуру трансформація звороту «попасти як муха в окріп» утруднена існуванням спорідненого фразеологізму з відмінною семантикою: «як муха в окропі» («хтось постійно зайнятий роботою; проворний, швидкий» [24, с. 412]). По-друге, ймовірна контекстуальна заміна «мухи» на «ведмедя〉 навряд чи сприятиме відтворенню комічного ефекту оригіналу: окріп та звичайна вода все ж таки різні речі. Семантично дистанційованими $є$ також лексеми «вода» та «щи», тож активізація російського звороту «попасться как кур во щи» у перекладі потребувала б зміни сюжету. 3 огляду на ці труднощі, I. Бондарь-Терещенко відмовляється від пошуку фразеологічної основи для каламбуру [25], а А. Глебовська розв'язує цю проблему за допомогою суб'єкт-предикатної сполуки «Мокрая история». Через полісемантичність предикату і прив'язаність до жаргонізму «мокрое дело» («убийство» $[19$, с. 328]) заголовок російського перекладача $\epsilon$ провокативним, однак відповідним сюжету і тому смішним. Фокалізація не збережена: в оригіналі дано чітке уявлення про адресата "trouble", у перекладі А. Глебовської така прозорість відсутня, а в редакції I. Бондаря-Терещенка вектор "trouble" зміщено остаточно. Оскільки учасниками вечірнього чаювання - «Чайної церемонії» - $є$ члени родини Браунів, на яких раптово зі стелі почала сочитися вода, артикулюється роль Падінгтона як ініціатора неприємностей. Назва «Чайна церемонія» переключає увагу реципієнта 3 проблем «Іншого» на негаразди «Свого», ініціюючи інверсію початкового наративного фокусу. Якщо ці модифікації змісту не були метою українського перекладача, доцільно було б спробувати обіграти фразеологічний зворот «ускочити по самі вуха»; контекстуальною альтернативою могла стати назва «По вуха у воді».

Заголовок "A Sticky Time" є типовим прикладом каламбурного зрощення актуалізованої внутрішньої форми із загальноприйнятним змістом
(Порівняємо: "come to a sticky end" = "come to a bad end" [22, с. 316]). Обидва смисли експлуатуються одночасно, вони посилюють, заміщують i заперечують один одного. Так, семантику "Sticky Time" як "trouble" змодельовано постійним нагромадженням маркерів небезпеки (будинок у диму, брудні вікна, заклинило двері); відчуття небезпеки знімається експлікацією причини ("Sticky Time" $\leftarrow$ приготування Падінгтоном ірисок); вказана причина зумовлює нерухомість Падінгтона, однак не через хворобу від надмірного вживання солодощів (очікувано), а внаслідок потрапляння карамелі на хутро (пуант гумору). "A Sticky Time" являє той нечастий випадок, коли в лексичному складі обох мов перекладу наявні засоби для збереження еквівалентності форми та змісту. Користуючись цією нагодою, І. Бондарь-Терещенко розгортає каламбур на базі фразеологізму «влипнути в історію» [26]. А. Глебовська та К. Сиверцева, попри періодичне спрямування у площину тексту смислових сигналів на зразок «Опять я влип в историю!...» [27, с. 90], надають перевагу емфатизації ключового концепту оповідання за допомогою рими: «Ириски в миске». Причина уникання каламбуру коріниться, ймовірно, у широкому розповсюдженні в російській мові (в українській, між іншим, також) евфемістичних зворотів, що апелюють до образу крадія: «прилипать к рукам» [20], «липкі руки» [24, с. 335]. Вибір А. Глебовської й К. Сиверцевої може бути зумовлений намаганням запобігти актуалізації у свідомості реципієнта того кластеру смислів, трансляція яких на «Іншого» - Падінгтона в плани автора оригіналу, вірогідніше за все, не входила. Втім назва «Липка пригода» I. Бондаря-Терещенка видається безпечною в цьому сенсі: багаторазово акцентовані смакові уподобання Падінгтона (любов до мармеладу та інших солодощів) формують настільки стабільний зв'язок між постаттю ведмедика й атрибутом «липкість», що відродження в процесі мовної гри потребуватиме не внутрішня форма фразеологізму, а радше його усталений зміст.

Специфікою як українського, так і російського перекладу назви "Paddington in a Hole" (буквальне значення чергової реалізації "trouble" [22, с. 166] пов'язане 3 намаганнями Падінгтона допомогти 
сусідові осучаснити кухню, що призводить до появи великого отвору у зовнішній стіні - майбутнього вікна) $є$ усунення авторського каламбуру за рахунок конструювання нового, етноспецифічного, тотожного для обох авторів (хоча і дещо відмінного за фокалізацією). Заголовки «Падінгтон прорубує вікно у світ»/«Как соседу окно прорубили» $є$ алюзією на запозичене О. Пушкіним у Ф. Альгароті ототожнення Петербурга 3 «вікном до Європи» («Природой здесь нам суждено / В Европу прорубить окно», поема «Мідний вершник»). Репрезентовані зворотом ідеї просвітництва («дать доступ просвещению, как окно - свету» $[23$, с. 567]) в ракурсі спрямовання ïх на опозицію «свій» (сусід-англієць) - «чужий» (Падінгтон-іноземець) i контекстуальну інверсію цієї опозиції, а також активну роль «Іншого» в процесі «виведення «Свого» у світ» сприяють інтерпретації перекладацького варіанту заголовку як пародії на стереотипну англійську етноцентричність, замкненість та любов до «закритих дверей».

Такий резонанс тональностей українського та російського перекладів $\epsilon$, однак, поодиноким випадком. Прагнення I. Бондаря-Терещенка досягти максимальної еквівалентності контрастує 3 тяжінням А. Глебовської та К. Сиверцевої до заміщення попередньо нейтральних заголовків оригіналу якісно новими формулами 3 елементами мовної гри. Відмінні продуктивні моделі відображення гумору можуть бути результатом різних уявлень про специфіку дитя- чої книги. Питання як та якою мірою слід виводити у заголовок жарт, заснований на реаліях, залежатиме від вибору перекладачем стратегії «одомашнення» комічного чи збереження національного колориту.

Висновки. Аналіз заголовків оповідань М. Бонда вкотре довів складність відтворення під час перекладу гумористичного компонента заголовку. У дитинно-орієнтованому дискурсі М. Бонда заголовок подеколи акумулює цілий кластер соціокультурних уявлень, породжених актуальними для Британії періоду виходу першодруку проблемами «інакшості». Концепт "trouble", визначальний для циклу письменника, реалізується в низці заголовків за посередництва етноспецифічних алюзій та каламбурів; спроби відобразити ці нюанси подеколи виводять наратив М. Бонда на межу перекладності. Вектор пошуку перекладацького компромісу балансує між схильністю до «привласнення» іноземного матеріалу та намаганням досягти максимальної еквівалентності тексту. Втім, хоча орієнтованість А. Глебовської та К. Сиверцевої на русифікацію дитячої книги і спричиняє зміну тональності і наративного фокусу комізму окремих заголовків, а тяжіння I. Бондаря-Терещенка до англізації не завжди рівнозначне прозорості англійського гумору для маленького читача, характеристикою обох перекладів є легкість та невимушеність стилю мовлення. Це створює перспективи для подальшого вкорінення історії Падінгтона в українській культурі.

\section{ЛІТЕРАТУРА}

1. Карасик В.И. Языковой круг: личность, концепты, дискурс. Волгоград : Перемена. 2002. 477 с.

2. Підгрушна О.Г. Відтворення англійського гумору в українському художньому перекладі : дис. ... канд. філ. наук : 10.02.16. Київський національний університет імені Тараса Шевченка. Київ, 2015. 227 с.

3. Smith A. Paddington Bear: A Case Study of Immigration and Otherness. Children's Literature in Education. 2006. Vol. 37. No 1. P. 35-50.

4. Кржижановский С.Д. Поэтика заглавий. Москва : Никитинские субботники. 1931. 32 с.

5. Эко У. Заметки на полях «Имени розы» / Пер. с итал. Е. Костюкович. Москва : Астрель, Corpus. 2012. $160 \mathrm{c}$.

6. Etkind А. Поэтика заглавий. Revue des études slaves. 1998. Tome 70. Fascicule 3. L'espace poetique. En hommage à Efim Etkind. P. 559-565.

7. Кухаренко В.А. Интерпретация текста : учебное пособие. Москва : Просвещение. 1988. 192 с.

8. Нестерова М.Н., Папулова Ю.К. "The Lambs of London" и/или «Лондонские сочинители»: о проблеме перевода заглавия. Вестник Московского университета. Сер. 22. 2014. № 3. С. 89-101.

9. Акашева Т.В., Рахимова Н.М. Функциональная нагрузка сильных позиций текста и их прагматическая адаптация при переводе. Евразийский союз ученых. Филологические науки. 2014. № 7. С. 80-82.

10. Влахов С., Флорин С. Непереводимое в переводе. Москва : Международные отношения. 1980. $343 \mathrm{c}$.

11. Zabalbeascoa, P. Humor and Translation - An Interdiscipline. Humor. International Journal of Humor Research. 2005. Vol. 18/2. P. 185-207.

12. Bond Michael. Paddington Complete Novels. Harper Collins Children's Books. 2013.

13. McLynn Frank. Crime and Punishment in Eighteenth Century England. New York : Routledge. 1989. 
14. The Random House College Dictionary. Revised Edition / Ed. by Jess Stein. New York : Random House. 1979. $1568 \mathrm{p}$.

15. Webster, W. "There'll always be an England": Representations of Colonial Wars and Immigration, 1948-1968. Journal of British Studies. 2001. Vo1. 40. P. 557-584.

16. Пропп В. Проблемы комизма и смеха. Москва : Лабиринт. 1999. 288 с.

17. Bond M. A Bear Called Paddington. Harper Collins Children's Books. 2015.

18. Shevit Z. Translation of children's Literature as a Function of its Position in the Literary Polysystem. Translation Theory and Intercultural Relations. Poetics Today (Special Issue). Vol. 2. No. 4. 1981. P. $171-179$.

19. Ожегов С.И. Словарь русского языка / Под ред. Н.Ю. Шведовой. Москва : «Советская Энциклопедия». $1973.846 \mathrm{c.}$

20. Ефремова Т.Ф. Новый словарь русского языка. Толково-словообразовательный. Москва : Русский язык. 2000. URL: https://www.efremova.info/ (дата звернення: 1.10.20).

21. Даль В.И. Толковый словарь живого великорусского языка: в 4 т. Санкт-Петербург-Москва : Типография М.О. Вольфа. 1882. Т. 4.704 с.

22. Longman Dictionary of English Idioms. Longman Group Limited. 1996. 388 p.

23. Михельсон М.И. Русская мысль и речь. Свое и чужое. Опыт русской фразеологии. Сборник образних слов и иносказаний. Санкт-Петербург : Типография акционерного общества «Брокгауз-Ефрон». 1912. $1161 \mathrm{c}$.

24. Словник фразеологізмів української мови / за ред. В.О. Винника. Київ : Наукова думка. 2003. 788 с.

25. Бонд М. Ведмежа на ім’я Падінгтон / Пер. з англ. І.С. Бондаря-Терещенка. Харків : Ранок. 2015. $132 \mathrm{c}$.

26. Бонд М. Пригоди ведмежати Падінгтона / Пер. 3 англ. І.Є. Бондаря-Терещенка. Харків : Ранок. 2014. $108 \mathrm{c}$.

27. Бонд М. Паддингтон путешествует: рассказы / Пер. с англ. А. Глебовской. Санкт-Петербург : Издательский Дом «Азбука-классика». 2007. 288 с.

\section{REFERENCES}

1. Karasik, V. (2002). Yazykovoj krug: lichnost', koncepty, diskurs. Volgograd: Peremena.

2. Pidgrushna, O.G. (2016). Vidtvorennya anglijskogo gumoru v ukrayinskomu hudozhnomu perekladi (Doctoral dissertation). Kyivskyj nacionalnyj universytet imeni Tarasa Shevchenka, Kyiv.

3. Smith, Angela. (2006). Paddington Bear: A Case Study of Immigration and Otherness. Children's Literature in Education, 37 (1), 35-50.

4. Krzhyzhanovskyj, S.D. (1931). Poetyka zaglavyj. Moskva: Nykytynskye subbotnyky.

5. Eko, U. (2012). Zametky' na polyah “Ymeny' rozy". Moskva : Astrel', Corpus.

6. Etkind, Alexander. (1998). Poetyka zaglavyj. Revue des études slaves, 70 (3), 559-565.

7. Kukharenko, V.A. (1988). Ynterpretacyya teksta. Moskva : Prosveshhenye.

8. Nesterova, M.N., Papulova, Yu.K. (2014). "The Lambs of London" y'/ yly' "Londonskye sochynytely": o probleme perevoda zaglavyya. Vestnyk Moskovskogo unyversyteta, 22 (3), 89-101.

9. Akasheva, T.V., Rahymova, N.M. (2014). Funkcyonalnaya nagruzka sylnykh pozycyj teksta y ykh pragmatycheskaya adaptacyya pry perevode. Evrazyjskyj soyuz uchenykh. Fylologycheskye nauky, 7, 80-82.

10. Vlahov, S., Floryn, S. (1980). Neperevodymoe v perevode. Moskva: Mezhdunarodnye otnoshenyya.

11. Zabalbeascoa, P. (2005). Humor and Translation, an Interdiscipline. Humor: International Journal of Humor Research, 18 (2), 185-207.

12. Bond, M. (2013). Paddington Complete Novels. Harper Collins Children's Books.

13. McLynn, Frank. (1989). Crime and Punishment in Eighteenth Century England. New York : Routledge.

14. Stein, J. (Ed.). (1979). The Random House College Dictionary. New York : Random House.

15. Webster, W. (2001). "There'll always be an England": Representations of Colonial Wars and Immigration, 1948-1968. Journal of British Studies, 40, 557-584.

16. Propp V. (1999). Problemy komyzma y' smekha. Moskva: Labyrynt.

17. Bond, M. (2015). A Bear Called Paddington. Harper Collins Children's Books.

18. Shevit, Z. (1981). Translation of children's Literature as a Function of its Position in the Literary Polysystem. Translation Theory and Intercultural Relations. Poetics Today (Special Issue), 2 (4), 171-179.

19. Ozhegov, S.Y. (1973). Slovar' russkogo yazyka. Moskva : Sovetskaya Encyklopedyya.

20. Efremova, T.F. (2000). Novyj slovar' russkogo yazyka. Tolkovo-slovoobrazovatelnyj. Moskva : Russkyj yazyk. Retrieved from: https://www.efremova.info/. 
21. Dal', V.Y. (1882). Tolkovyj slovar' zhyvogo velykorusskogo yazyka. T. 4. Sankt-Peterburg-Moskva : Typografyya M.O. Volfa.

22. Longman Dictionary of English Idioms. (1996). Longman Group Limited.

23. Mykhelson, M.Y. (1912). Russkaya mysl' y rech. Svoe y' chuzhoe. Opyt russkoj frazeologyy'. Sbornyk obraznykh slov y ynoskazanyj. Sankt-Peterburg : Typografyya akcyonernogo obshhestva "Brokgauz-Efron".

24. Vynnyk, V.O. (Ed.) (2003). Slovnyk frazeologizmiv ukrayinskoyi movy. Kyiv: Naukova dumka.

25. Bond, M. (2015). Vedmezha na im'ya Padington / Per. z angl. I.Ye. Bondarya-Tereshhenka. Kharkiv : Ranok.

26. Bond, M. (2014). Prygody vedmezhaty Padingtona / Per. z angl. I.Ye. Bondarya-Tereshhenka. Kharkiv : Ranok.

27. Bond. M. (2007). Paddyngton puteshestvuet. / Per. s angl. A. Glebovskoj. Sankt-Peterburg: Yzdatelskyj Dom "Azbuka-klassyka". 